\title{
DEFINING RELIGION IN OPERATIONAL AND INSTITUTIONAL TERMS *
}

\author{
A. Stephen Boyan, Jr. $\dagger$
}

I

On September 4, 1965, the National Guardian published an advertisement by a "Christian Communist Movement." The headline read, "It's time to bridge the gap . . . the apostles of Christ were Communists."

And all they that believed were together, and had all things common. Their possessions and goods they sold, and divided them all, according as every one had need.

The Bible-Acts $2: 44,45$.

From each according to his ability, to each according to his need.

\section{Karl Marx. ${ }^{1}$}

The advertisement went on to proclaim that "God is pro-communist. Otherwise he would not have provided the apostles with the power to perform miracles while they and thousands of their converts practiced communism." 2 The Christian Communist Movement claims to be religious-is it possible to deny this characterization for first amendment or other legal purposes?

One commentator has analyzed communism as a religion:

The term "religion" as used today might include almost any kind of ultimate concern with or without an act of personal commitment. The Communist, certainly, is grasped by an ultimate concern which for him is a matter of life or death, not only personally but also theoretically in terms of his own insignificance, his not-being and worthlessness except [as] he participate[s] in the realization of his Messianic age, his classless society. ${ }^{3}$

* I am indebted to Professors Marc Galanter, C. Herman Pritchett, and Herbert Storing for their many suggestions in the preparation of this article. Naturally the ideas expressed herein are solely the responsibility of the author.

$\dagger$ Assistant Professor of Political Science, Pennsylvania State University. A.B. 1959, Brown University; M.A. 1961, Tufts University; Ph.D. 1966, University of Chicago.

1 National Guardian, September 4, 1965, at 8.

2 Id.

3 Stahmer, Defining Religion: Federal Aid and Academic Freedom, in ReLIGION AND THE PuBLIC ORDER, 116, 128-29 (D. Giannella ed. 1963). 
If this theoretical description of religion were translated into a legal definition, the Christian Communist Movement might fall within it and become entitled to certain legal privileges and exemptions. ${ }^{4}$ The Movement could support this result by arguing that the Supreme Court's decision in Fowler $v$. Rhode Island ${ }^{5}$ prohibits states from discriminating against a group on the basis of that group's unusual or unpopular religious beliefs.

In addition, if the Movement were accepted as a religion, the free exercise clause of the first amendment would entitle it to exemptions from certain duties and prohibitions that persons and organizations of a non-religious character must obey. For example, the free exercise clause recently has been held to protect the right of a child in a public school to refuse to stand for the singing of the National Anthem, ${ }^{B}$ the right of a woman to refuse to serve as a juror ${ }^{7}$ and the right of a religious organization of Indians to possess a drug in contravention of a state narcotics contol law. ${ }^{8}$ To the objection that this would be unreasonable, the Movement could reply that the United States Supreme Court has indicated that the government may not deprive one religious group of benefits enjoyed by other religious groups or subject it to additional burdens. In Everson v. Board of Education, ${ }^{9}$ the Court stated that:

The "establishment of religion" clause of the First Amendment means at least this: Neither a state nor the Federal Government can set up a church. Neither can pass laws which aid one religion, aid all religions, or prefer one religion over another. ${ }^{10}$

Despite the importance of the legal definition of religion, judicial opinions dealing with it have often appeared dogmatic or confused. It

4 In the area of taxation, for example, religious organizations are commonly entitled to tax exemptions on their houses of worship, with such exemptions sometimes extending to such facilities as parsonages and publication houses as well. See, e.g., PA. Const. art. 9, \&1 (permitting legislative exemption from taxation of "actual places of religious worship"); First Baptist Church v. Pittsburgh, $341 \mathrm{~Pa}$. 568, 20 A.2d 209 (1941); Philadelphia v. Barber, 160 Pa. 123, 23 A. 644 (1894); In. Const. art. $9, \S 3$ (permitting legislative exemption of property used for religious purposes); People v. Catholic Bishop, 311 I1l. 11, 142 N.E. 520 (1924); Congregational Sunday School v. Board of Review, 290 IIl. 108, 125 N.E. 7 (1919). On the federal level, contributions to religious organizations may also be partially tax deductible. INT. REV. CODE of $1954, \S 170(\mathrm{~b})$.

5 345 U.S. 67 (1953) (state cannot discriminate against one religion by distinguishing sermons (immune from regulation) from addresses (subject to regulation)).

ESheldon v. Fannin, 221 F. Supp. 766 (D. Ariz. 1963).

7 In re Jenison, 375 U.S. 14 (per curiam), on remand, 267 Minn. 136, 125 N.W.2d 588 (1963).

8 People v. Woody, 61 Cal. 2d 716, 394 P.2d 813, 40 Cal.-Rptr. 69 (1964).

9330 U.S. 1 (1947).

$10 \mathrm{Id}$. at 15 (emphasis added). 
is the purpose of this article to review some of the major judicial attempts to define religion and to suggest some definitions which, it is hoped, will avoid some of the difficulties which now surround the subject.

\section{II}

In assessing the courts' attempts ${ }^{11}$ to define religion, it is important to understand the criteria being used. For example, does religion involve a belief in a Supreme Being? Is it possible or necessary to define such a term? Does religion necessarily involve an institutional structure? To what extent is it relevant that an individual or group labels or refuses to label a particular belief religious? Must religion involve beliefs at all? Must it involve some sort of ritual? Must its adherents meet, regularly or otherwise? Must there be worship, meditation or designated leaders who perform specified roles? Judicial opinions, while grappling at times with all of these problems, have treated extensively only the problem of belief in a Supreme Being; no opinion has weighed the relative importance of all of these factors.

The traditional understanding of religion in this country has involved both a concept of God, usually a theistic God ${ }^{12}$ and an institution for His worship, generally understood as a church in the Christian sense. The remarks of John Locke reflect the essence of this understanding:

The end of a religious society . . . is the public worship of God . . . . A church, then, I take to be a voluntary society of men, joining themselves together of their own

11 Even where statutes define religion, e.g., Universal Military Training and Service Act $\S 6(j), 50$ U.S.C.A. App. $\$ 456(j)$ (Supp. 1967), the ultimate burden of defining religion for legal purposes has fallen on the courts. See, e.g., United States v. Seeger, 380 U.S. 163 (1965). This function of the state has not gone unquestioned. The New Jersey Superior Court has taken the position that:

There is no right in a state or an instrumentality thereof to determine that

a cause is not a religious one. Such a censorship of religion as the means

of determining its right to survive is a denial of liberty protected by the

First Amendment and included in the liberty which is within the protection of the Fourteenth Amendment.

Kolbeck v. Kramer, 84 N.J. Super. 509, 574, 202 A.2d 889, 892 (1964). However attractive this position may first appear in theoretical terms, it becomes difficult to maintain in practice; if it were accepted, any organization could call itself a religion and limits would have to be placed on the freedom granted by the free exercise clause.

12 In this article, the terms theism and deism, unless otherwise qualified, shall be understood in the ordinary dictionary sense. According to WEBSTER'S THIRD NEW INTERNATIONAL DICTIONARY 2370 ( $P$. Gove ed. 1966), theism is a "belief in the existence of a god or gods; [specifically] . . . belief in the existence of one God who is viewed as the creative source of man, the world, and value, and who transcends and yet is imminent in the world . . . Deism is a "natural religion based on human reason and morality, on the belief in one God who after creating the world and the laws governing it refrained from interfering with the operation of those laws, and on the rejection of every kind of supernatural intervention in human affairs ...." Id. at 595 . 
accord in order to achieve the public worshipping of God in such manner as they judge acceptable to $\mathrm{Him}$, and effectual to the salvation of their souls. ${ }^{13}$

An example of a judicial expression of this traditional understanding was provided by the Nebraska Supreme Court, which said, in State v. Scheve, ${ }^{14}$ that it was the duty of the state to protect "every religious ... society whose members are accustomed to come together for the purpose of worshipping the Supreme Being." 15

One of the most important judicial justifications for the traditional understanding of religion is found in the opinion of the United States Court of Appeals for the Ninth Circuit in Berman v. United States, ${ }^{16}$ where the court interpreted a provision in the Selective Service Act of $1940^{17}$ exempting from combatant military service any person who by "religious training and belief, is conscientiously opposed to participation in war in any form." 18 The court maintained that the term "religious training and belief," was used to distinguish a mere "conscientious social belief, or a sincere devotion to a high moralistic philosophy," from a religious belief based upon an individual's belief in his "responsibility to an authority higher and beyond any worldly one." 19

In support of this interpretation, the court first looked to the intention of the framers of the Constitution. The court argued:

It would be quite ridiculous to argue that the use of the word "religion" would have been understood by the authors . . . as meaning to be inclusive of morals or of devotion to human welfare or of policy of government. ${ }^{20}$ 1937).

$13 \mathrm{~J}$. Locke, A Letter Concerning Toleration 22, 20 (2d ed. P. Romanell ed.

1465 Neb. 853, 93 N.W. 169 (1903).

$15 \mathrm{Id}$. at $879,93 \mathrm{~N} . \mathrm{W}$. at 170 . Another example of this judicial understanding appears in Hale v. Everett, 53 N.H. 9 (1868), where the court quoted approvingly from:

Robins' Religions of all Nations [where at] page 6, it is said "the religious world is divided into four grand systems, viz.: Christianity, Judaism, Mohammedanism, and paganism. . . Paganism-of all those who have not the knowledge of the God, but worship idols. . . . The only people who may not be classed under one of these four divisions are the deist and the atheists, the latter differing from them all, in owning no religion, and the former in owning no divine revelation as the foundation of their religion."

Id. at 54. See also Davis v. Beason, 133 U.S. 333, 342 (1890); United States v. Macintosh, 283 U.S. 633, 633-34 (1931) (Mr. Chief Justice Hughes, dissenting).

16156 F.2d 377 (9th Cir.), cert. denied, 329 U.S. 795 (1946). (1940).

17 Selective Training and Service Act of 1940 , ch. $720, \S 5(\mathrm{~g}), 54$ Stat. 885, 889

$18 \mathrm{Id}$.

$19156 \mathrm{~F} .2 \mathrm{~d}$ at 380 .

$20 I d$. 
There is some historical support for the court's position. For example, in 1784 James Madison defined religion as "the duty which we owe to our creator, and the manner of discharging it." ${ }^{21}$ Madison also referred to the "Governor of the Universe," "The universal sovereign," "God" and the "Supreme Law-Giver of the Universe." 22 These references seem to support the proposition that, for Madison at least, some notion of divinity was an essential aspect of religion.

The court then asked whether, as a matter of social fact, the generally accepted definition of religion had changed, notwithstanding the intention of the framers. The court found that some change had taken place; however, it said:

[A]11 the discoveries of science and the deepest reach of minds do not fill a life or satisfy the soul hunger to understand the daily joys and sadnesses and disappointments of life or to understand the ultimate purpose of creation. . . . The area of our logical equations comes to an end, but we do not assign all beyond as a great vacancy. . . . The intellectually satisfying Meditations of Marcus Aurelius do not suffice for the boy in the fox hole, under fire. His philosophy is not called upon in that agonizing hour. He goes direct to his god to bolster his flagging strength and courage. ${ }^{23}$

This argument is not fully convincing. Admittedly in hours of great need, when the logical equations do come to an end, most people call upon God for emotional support and for an understanding of life in its basic sense. But there may be people who turn to something other than a God, to provide them with the same emotional support and understanding of life. Indeed, it is difficult to understand that the court rested its theistic approach on whether a "boy in the fox hole" does or does not rely on God, as an empirical proposition. Rather, the example is used to confirm the court's understanding that at some point, "Faith 'which passeth all understanding' carries on." It is this phenomenon which is religious in the court's view. If it is this phenomenon which is religious-a psychologically defined phenomenon of supra-rational reliance on a support-giving fundamental-the court's theistic conclusion is not compelled; there is no reason why, for certain persons, religious faith may not have as its ultimate object something other than the traditional God.

But the court found more support for its position. Congress, it said, presumably was aware of the traditional approach of the Supreme

21 Madison, A Memorial and Remonstrance on the Religious Rights of Man, in Cornerstones of Religious Freedoar in America, 84 (J. Blau ed. 1964). 
Court to religion. Yet, in writing the Selective Service Act, Congress did nothing to indicate dissatisfaction with the Supreme Court's interpretations of the term. Pronouncements by the Court accepting religion as belief in a "Creator" and "God" were in accord with "man in the street" opinion, and Congress could reasonably be expected to reflect this common understanding. ${ }^{24}$

Berman represents a judicial expression of the main arguments in defense of the traditional understanding of religion. Perhaps these arguments were so thoroughly made in Berman because the traditional understanding was under serious attack by $1946 .^{25}$ Three years earlier, another court of appeals had defined religion quite differently under the same statute.

III

The Court of Appeals for the Second Circuit began to move toward a broad definition of religion in 1943 in United States $v$. Kauten, ${ }^{26}$ another conscientious objector case. Kauten indicated on his Selective Service questionnaire that he was opposed to participating in all war. But in answering the question whether this opposition was by virtue of "religious training and belief," Kauten crossed out the word "religious" and noted that, "this is not my case." 27 His request for conscientious objector status was denied; this led to an induction order and his prosecution for refusing to obey that order. The court

24 It is especially difficult to impute to Congress an intention to broaden the current legal definition of religion in the context of an exemption to a draft law. A broad exemption would frustrate the public policy underlying the draft law itself- the prompt and efficient prosecution of war, which is a matter of utmost concern to the state. Thus, in this circumstance, it would seem more reasonable to assume that Congress intended to confine the category of exemptions within narrow limits. In other circumstances, Congress might reasonably take a broader view. If the issue were, for example, whether the leader of a non-theistic organization claiming to be religious is entitled to celebrate marriages in the District of Columbia, Congress could well consider that no public policy objective would be defeated if it answered that question affirmatively.

Perhaps more critical evaluation should be made of the courts further argument that most English language dictionary definitions of religion also require "a belief in some superhuman power" or the "service and adoration of God." Berman v. United States, 156 F.2d 377, 381 (9th Cir. 1946). An objection to this may be that, unless all dictionary definitions of religion have reference to a belief in a God, the dictionary does not bolster the court's position. The court did not, and indeed could not, assert such a finding. Yet, in favor of the court's argument is the limited purpose for which it was made--to further demonstrate the common understanding of what religion is, which the Congress, without defining religion otherwise, should be presumed to have reflected.

25 It remained true, however, that with few exceptions, e.g., Ex parte Jentzsch, $112 \mathrm{Cal} .468,44$ P. 803 (1896); the predominant judicial understanding of religion was along traditional lines. E.g., Opinion of the Justices, 309 Mass. 555, 34 N.E.2d 431 (1941) ("Supreme Being"); Nikulnikoff v. Archbishop, 142 Misc. 894, 901, 255 N.Y.S. 653, 663 (Sup, Ct. 1932) ("to render God the worship due to Him").

26133 F.2d 703 (2d Cir. 1943).

27 Id. at 707 n.2. 
of appeals found no error in the denial of conscientious objector status because Kauten was obviously a non-religious conscientious objector. In the course of the opinion, Judge Augustus Hand gratuitously offered a definition of religion:

Religious belief arises from a sense of the inadequacy of reason as a means of relating the individual to his fellow men and to his universe-a sense common to men in the most primitive and in the most highly civilized societies. It accepts the aid of logic but refuses to be limited by it. It is a belief finding expression in a conscience which categorically requires the believer to disregard elementary self-interest and to accept martyrdom in preference to transgressing its tenets. . . [A] conscientious objection to participation in any war under any circumstances . . . may justly be regarded as a response of the individual to an inward mentor, call it conscience or God, that is for many persons at the present time the equivalent of what has always been thought a religious impulse. ${ }^{28}$

This statement, which amounts to a broad, non-theistic definition of religion, was understood to be of general applicability and was quoted approvingly by $\mathrm{Mr}$. Justice Frankfurter later in the same year. ${ }^{29}$ Moreover, in two subsequent cases, the Court of Appeals for the Second Circuit released conscientious objectors from prison because, on the basis of the dictum in Kauten, selective service officials had erred in finding their non-theistic beliefs to be non-religious. ${ }^{30}$

Although Judge Hand's statement is not entirely clear, ${ }^{31}$ it is possible to use it as a starting point from which to formulate a legal standard which distinguishes religion from non-religion and eliminates the necessity for a "belief in God":

religion is a belief in a final reality, based not entirely on reason, relating the individual to his fellow man and the universe, and finding expression in veneration and an inward mentor called conscience. ${ }^{32}$

$28 I d$. at 708 .

29 West Virginia State Bd. of Educ. v. Barnette, 319 U.S. 624, 658-59 (1943) (Frankfurter, J., dissenting).

30 United States ex rel. Reel v. Badt, 152 F.2d 627 (2d Cir. 1945), cert. denied, 328 U.S. 817 (1946); United States ex rel. Phillips v. Downer, 135 F.2d 521 (2d Cir. 1943).

31 There are a number of aspects of this definition of religion as formulated by Judge Hand which seem unclear, e.g., what kind of belief is it, and, what is meant by "conscience or God" as an inward mentor?

32 Conscience is defined in Webster's ThIRD NeW International Dictionary

(P. Gove ed. 1966) as

the sense of right or wrong within the individual . . . : The awareness of the moral goodness or blameworthiness of one's own conduct, intentions, or character together with a feeling of obligation to do or be that which is recognized as good often felt to be instrumental in producing feelings of guilt or remorse for ill-doing. ..." 
Or, to state it differently, religion is a belief which:

(1) is based not entirely on reason or empirical evidence;

(2) refers to a final or ultimate reality;

(3) relates the believer to his fellow men and the universe;

(4) finds expression in an attitude of veneration or devotion towards the final reality;

(5) finds expression in an inward mentor called conscience..$^{33}$

At the outset it should be emphasized that this is a definition of religion only in an operational sense, a description of the beliefs operative within an individual, distinct from a definition in an institutional sense, which refers to patterns of associated behavior. ${ }^{34}$ Furthermore, of the five characteristics of the belief, only the first can be identified as such by the outside observer, that is, as based not entirely on reason or empirical evidence; the other four characteristics are necessarily evident only to the believer himself. Thus, only the believer knows the nature and relationships of this final reality, and how his belief relates him to his fellow man and the universe. Crucial to religion is the individual's belief, ${ }^{35}$ a belief in something which imposes obligations superior to the obligations arising from human relationships. We think almost by reflex of some notion of God. But the revered final reality could even be a fundamental rule by which man derives norms for conduct, as, for example, in some understandings of Judaism or Unitarianism. The typical religious individual believes that there is an omnipotent God which must be obeyed. His beliefs about God or His will need be true only subjectively-not objectively. For the purposes of the Selective Service Act, an individual who believes in a God to whom he has duties superior to those arising from any human relation, one of which is not to kill, is a conscientious objector regardless of whether the draft board shares this belief; a draft board judges only the sincerity of the individual in stating this belief.

Suppose, however, an individual believes there is a Being prior to man, beyond temporal reality, known to those who believe and who must be obeyed, but he refuses to label this being God. Is that individual non-religious? This would seem to be a silly semantic distinc-

33 Certain words may be substituted for others in the definition without changing its meaning. Thus "ultimate" may be substituted for "final" reality (the latter is not intended to be understood in an exclusively temporal sense); similarly, "devotion" or "reverence," as a description of a claimant's attitude, may be substituted for "veneration."

34 See text accompanying note 37 infra, for a definition of a religious institution, and a discussion of why a religion must be defined in both an operational and an institutional sense.

35 This view is consistent with Locke's understanding: "; + true religion consist[s] in the inward and full persuasion of the mind ...." LockE, supra note 13, at 18 . 
tion. The only reasonable conclusion is that a man who believes in the existence of something which has the attributes of what other persons call God, and which has the same meaning for him, is a religious man.

However, what of an individual who believes in something which does not have the descriptive characteristics ordinarily attributed to a supernatural Being or God, but which has the same ultimate meaning for the individual as God does to the believers in Him? In Taoism, for example, the Tao was before the earth or sky, silent, aloof, alone, changing not, touching all, great and infinite. One must love and follow Tao, yet Tao is indescribable and nameless. ${ }^{36}$ Is a believer in Tao a religious man? According to our suggested definition he would be: because the function served by the belief for the individual is decisive. For the Taoist, Tao does relate the individual to his fellow man and to the universe, and the belief results in characteristic attitudes. In serving these functions for the believer, such a belief corresponds to the Christian belief in God.

The function of belief is crucial in the operational definition of religion. But what of those persons who say they believe in God, but for whom this belief apparently serves no function either in influencing their behavior or in deepening their understanding of the universe or fellow man? Such people may nominally be members of a church, noting on work applications that they are, for example, Methodists. At the same time, objectively speaking, their behavior in no way seems influenced by the teachings of Methodism; they do not even go to their church frequently. These people do not think that the belief system of their church is wrong; they just do not think about the beliefs to a great extent. Yet their statement that they are Methodists is accepted at face value and few would call them irreligious.

The fact that such people generally are considered to be religious indicates the necessity for having an institutional definition of religion, in addition to an operational definition. A religious institution, or a religion in an institutional sense, consists of any association of practices, rituals or ceremonies intended to confirm, manifest, express or promote a belief, which for some persons is operationally religious. ${ }^{37}$

${ }^{36}$ Lao TzU, Tao Te Ching (R. Blakney transl. 1955). Tao is often translated in English as "Way" but understanding its meaning on the basis of brief translation or even definition is often difficult for men trained in Western thought. Consider the dictionary definition:

Taoism: the unitary first principle from which all existence and all change in the universe spring: the unconditional amenable source of all reality that transcends being and nonbeing by standing above and beyond all distinctions $\mathrm{b}$ : eternal order of the universe. . .

WebsteR's ThIRD NEW InTERNational Dictionary 2338 (P. Gove ed. 1966).

37 The belief promoted by the institution must have been operationally religious at some point in time. The persons for whom the belief is operationally religious need not be alive; there may be a sacred writing proving the operationally religious nature of the belief. 
A religious person may also be one who is associated with a religious institution, as well as one who himself is religious in an operational sense. Our hypothetical Methodist, then, is religious in that he belongs to an institution, ${ }^{38}$ the Methodist church, which consists of rituals and ceremonies intended to express, to confirm and to promote the belief of Methodism, which, for some Methodists, is religious in an operational sense. Likewise, a person who practices asceticism is also religious, for this is a practice intended to express, confirm or promote a belief which for some persons is operationally religious.

If this distinction between religion as an operation of the mind and religion as an institution is kept in mind, few difficulties will arise for legal purposes. ${ }^{39}$ The alternatives to the use of such definitions for religion would seem to be to permit anyone to call any belief a religion, an overly relativistic position, or to insist on the traditional theistic definition, which is too rigid. Obviously to permit citizens to label any set of beliefs as religious would make it impossible for a legislature to use religion as a basis of classification, even if only to promote its free exercise. It could not exempt, for example, persons whose religious beliefs required them to observe another day as their Sabbath from the operation of the Sunday closing laws. If any belief were a religious belief, anyone could exempt himself from the operation of the Sunday closing laws by giving any reason.

On the other hand, a theistic definition is too narrow. It results in legal classifications having little relationship to actual developments in the religious field. The law must deal with real people in real social situations. Law which remains static becomes irrelevant and fails to serve justice. $^{40}$ If changes in social patterns and opinions are reason-

38 To the person so engaged, this may be a peripheral or inessential way of characterizing this performance, but the outside observer can identify the person's behavior as institutionally religious.

39 In the conscientious objector situation, for example, the individual involved must be religious in the operational sense; he personally must believe that his inward mentor, conscience, prevents him from participating in war. Naturally there can be, in this vast area of human experience, some superficially complicated situations. An individual may make his religious institution his religion in an operational sense. His institution might become his final reality, relating him to his fellow man, and the teachings of his institution or its ceremonies and rituals might constitute or provide his inward mentor. He may not articulate this or any belief at all which neatly fits the operational definition-but he does know and assert that he must follow the teachings of his religious institution, in terms of belief and practice. As in other situations, the only test will be whether this adherence is sincere. But see note 38 supra.

40 For whatever be the superstructure and coping-stone of justice, it can have neither stable strength, nor utility nor beauty, unless it is built squarely upon the ground of actual social relations in the time and place; of materials apt for the heat and stress of the actual social climate; and of a design which has regard to the accommodation which men actually need, and to their tastes and capacities.

J. Stone, The Province and Function of Law 784 (1950). 
able and susceptible of judicial formulation, the law has the obligation to incorporate these changes in order to remain relevant to the problems and people it addresses.

It is true that a number of non-theistic beliefs originating in eastern cultures have been recognized as being religious for legal purposes. But the relevance of a liberal definition of religion is best established by observing some recent developments in the Christian tradition. The theology of the late Dr. Paul Tillich, for example, does not involve a belief in the traditional God. Yet it has been widely recognized and accepted as a legitimate expression of Protestant Christianity. As the late Jesuit scholar, Gustave Weigel, put it: "Any witness of the Protestant reality looks for someone to give a unified meaning to the whole thing. I believe I have found that man in Professor Paul Tillich." 41

The non-theistic definition of religion proposed here is not based on the content of belief. Under the definition Dr. Tillich was religious-not because of what he believed, but because of what his beliefs meant to him. Those who insist on theism, however, must exclude him (and, by implication, possibly his distinguished theological admirers as well ${ }^{42}$ ). It is difficult to understand the practical justification for such a result.

A non-theistic and non-deistic definition of religion is not only reasonable and susceptible of judicial formulation, but also can be reconciled with the purposes of the framers. On the whole it may be conceded that these men had a theistic God in mind when they referred to religion. But this does not mean that references to religion in the Constitution must be confined to mean only theistic beliefs. The framers conceived of a distinction between matters pertaining to the state and matters pertaining to God. The framers also recognized that men's allegiance to their God would be superior to the allegiance owed to man himself, or to the state. Their purpose, however, was not to establish "true" notions of religion in the Constitution; it was rather to place limits on legitimate state power as against the individual. The framers understood that man's allegiance to God was not severed when civil society was formed to accomplish certain human purposes. Thus, it is of the same constitutional significance that today men give such allegiance to equivalent objects, not called God, but having the same meaning for them. The first amendment was

41 Quoted in N.Y. Times, Oct. 23, 1965, at 31, col. 3.

42 E.g., Dr. Gerald Bratuer, Dean, University of Chicago Divinity School, who called Dr. Tillich "[theology's] . . . most eloquest spokesman". N̄̇wswEEK, Nov. 1, 1965 , at 60 . Many other contemporary religious ideas are relevant to a discussion of liberalization of the theistic definition as well, such as Unitarianism-Universalism, to say nothing of the "death of God" movement. 
designed to limit state intrusion into the area of "operations of the mind." Thomas Jefferson recognized this when he said:

The error seems not sufficiently eradicated, that the operations of the mind, as well as the acts of the body, are subject to the coercion of the laws. . . . The rights of conscience we never submitted, we would not submit. We are answerable for them to our God. The legitimate powers of government extend to such acts only as are injurious to others. But it does me no injury for my neighbors to say there are twenty gods, or no God. It neither picks my pocket nor breaks my leg. ${ }^{43}$

Government officials have no special competence to judge the beliefs of other men which relate them to their fellow men and the universe, and which help them distinguish right from wrong. This is a fundamental, personal matter. The competence of government, according to the Constitution, is with public affairs. Of course "morals or . . . devotion to human welfare or . . . policy of government," 4 as the Berman court put it, were subjects assigned to the legislature. But the definition proposed here clearly requires religion to involve more than morals or welfare or government; the theists err in assuming that only a belief directed toward God concerns more than these subjects.

In concluding this section, perhaps it is helpful to apply the proposed definition of religion to answer the questions posed at the beginning of this discussion. Does religion necessarily involve a belief in a Supreme Being? The answer is no, unless that term refers only to any final reality of the type discussed in the definition above. ${ }^{45}$ May any individual belonging to no religious sect be religious? Yesonly an individual can be religious in the operational sense, although the burden, of course, should be on individuals seeking government recognition of religious claims to articulate their belief. ${ }^{46}$ It follows then that religion does not necessarily involve an institutional structure.

To what extent should it be legally relevant that an individual or group labels or refuses to label a particular belief as religious? It is

43 Jefferson, Notes on Virginia: Query XVII, the Different Religions Received into That State, in CoRnerstones of Retigrous FreEDOM IN AMrerica, 81 (J. Blau ed. 1964) (emphasis added).

44 Berman v. United States, 156 F.2d 377, 380 (9th Cir.), cert. denied, 329 U.S. 795 (1946).

45 See text accompanying notes 33-36 supra, 79 infra; United States v. Seeger, 380 U.S. 163 (1965).

46 If he proves, instead, his adherence to some sacred writing, by definition he proves his adherence to a religious institution. 
most relevant. A refusal to label a belief as religious, while in a legal context asserting a freedom or privilege granted on the basis of religion, seems inconsistent although it is not unknown. ${ }^{47}$ Under the standard proposed here, a court should be required to make clear to the claimant what it means by religion, because he might understand the term only in a conventional institutional sense. ${ }^{48}$ However, if an individual maintains that his belief, even including a belief in God, is not religious, it is not for the government to say that it is.

Must religion involve beliefs at all? Yes, but not in the same way for everybody. Some persons merely engage in rituals and ceremonies. Others see these practices as confirmation or promotion of beliefs which are religious. The persons who engage in ceremonies and rituals acknowledge some kind of identification with people for whom these beliefs are operationally religious. The point is that, at least indirectly, religion involves belief. ${ }^{49}$

Must religion involve some sort of ritual? Must its adherents meet? Must there be designated leaders who perform specified roles? The answers to these questions turn on the distinction between religion in its operational and institutional senses. Religion for the individual does not necessarily involve ritual, although for many it will. But meetings, rituals, ceremonies and specialized designated leaders are all part of what has been called a religious institution. In the nature of things, most individuals holding religious beliefs seek confirmation or promotion of these beliefs through association with others, but an institutional aspect is not essential. Thus, the answer to each of the questions is no, when speaking of religion in an individual; yes, when referring to an institution of religion.

These, then, are the standards proposed for legally determining the existence of religion. Other legal tests not involving a belief in God also have been proposed and must be compared with the tests suggested here.

\section{IV}

In Fellowship of Humanity v. County of Alamed $a,{ }^{50}$ the California First District Court of Appeals stated that theism is not an essential

47 Jehovah's Witnesses have denounced all religion as a "snare and a racket." Douglas v. City of Jeanette, 319 U.S. 157, 167 (1943) (separate opinion of Jackson, J.).

48 E.g., in United States v. Kauten, 133 F.2d 703 (1943), under the standard proposed here, the Selective Service System would have been required to explain to Kauten that it meant religion in the operational sense.

49 In Morey v. Riddell, 205 F. Supp. 918 (S.D. Cal. 1962), a church with no distinctive identifying name, written constitution, by-laws or operational guide other than the Holy Bible was conceded to be "religious" for the purpose of granting individuals tax deductions for contributions to the church under INT. REv. CODE of 1954, $\$ 170$. This is consistent with the definition here: the belief is in God whose Biblical word is so revered that it must not be obscured by the "arbitrary gloss" of a denominational name and a written organizational guide.

60153 Cal. App. 2d 673, 315 P.2d 394 (1957). 
element of religion and engaged in a full discussion of its reasons for taking this position. The issue was whether the Fellowship of Humanity should be exempt from taxation on its property by reason of California's constitutional provision exempting property and buildings "used solely and exclusively for religious worship." 51 The court argued that tax exemptions for religious property are justified only because the churches perform activities which promote the public welfare. Since the Fellowship of Humanity's activities "in all respects . . . are similar to those of the theistic groups, except for their belief or lack of belief in a Supreme Being . . . . It therefore follows, that the constitutional exemption is equally applicable to both groups." 52

The Court further argued that a proper interpretation of "religion" in tax exemption laws "should not include any reference to whether the beliefs involved are theistic or nontheistic." 53 The Court suggested different criteria for defining religion, observing that some authorities recognize non-theistic beliefs as religious and noting that any judicial determination of the validity or content of a belief is foreclosed by United States $v$. Ballard. ${ }^{54}$

Thus the only inquiry in such a case is the objective one of whether or not the belief occupies the same place in the lives of its holders that the orthodox beliefs occupy in the lives of believing majorities, and whether a given group that claims the exemption conducts itself the way groups conceded to be religious conduct themselves. The content of the belief, under such test, is not a matter of governmental concern.

Under this test the belief or non-belief in a Supreme Being is a false factor. The only way the state can determine the existence or nonexistence of "religious worship" is to approach the problem objectively. . .

Religion simply includes: (1) a belief, not necessarily referring to supernatural powers; (2) a cult, involving a gregarious association openly expressing the belief; (3) a system of moral practice directly resulting from an adherence to the belief; and (4) an organization within the cult designed to observe the tenets of belief. ${ }^{55}$

61 CaL. Const. art. XIII, §11/2.

52 Fellowship of Humanity v. County of Alameda, 153 Cal. App. 2d 673, 698, 315 P.2d 394, 410 (1957).

53 Id. at 693,315 P.2d at 406 .

54322 U.S. 78 (1944) (only issue in mail fraud case involving defendant's religious belief was his good faith, and not the truth or falsity of his beliefs).

55153 Cal. App. 2d at 692-93, 315.P.2d at 406. 
The first portion of this definition, the "parallel position" standard, is compatible with the test proposed.above. ${ }^{58}$ However, the court also required a cult, involving a gregarious association openly expressing a belief. But a cult is only an aspect of religion in an institutional sense; a solitary individual also can have a religion. Likewise, the court requires an organization within the cult designed to observe the tenets of belief; yet religion may exist without any organization. The court states that a system of moral practice results from adherence to a religious belief, but must a person who says he is religious actually have such a system? One way to answer this question, as well as to solve the other problems under the court's definition, would be to introduce operational-institutional categories. The court did not seem to have anticipated that once a non-theistic definition of religion was formulated, difficulties of this nature would arise.

The opinion of the United States Court of Appeals for the District of Columbia in Washington Ethical Society v. District of Columbia ${ }^{57}$ suggests the possibility of another test by which courts can determine whether a non-theistic group is eligible for the tax exemption granted to religious organizations. The issue in that case was whether the society's building should be tax exempt, as one "primarily and regularly used by its congregation for public religious worship." ${ }^{5 s}$ The court held that the society's building was exempt under the statute. It observed that the activities taking place in the building were very similar to activities taking place in many "formal or traditional church organizations." 59 The Society had regular Sunday services which were spiritually guided by a Leader and at which members sang, meditated and read from the Bible. Furthermore, the court felt that religion was not a rigid concept, and "to construe exemption so strictly that unorthodox or minority forms of worship would be denied the exemption benefits granted to those conforming to the majority beliefs might well raise constitutional issues." ${ }^{0}$ The court explicitly disclaimed decision as to whether the Ethical Society is "in an ecclesiastical sense a religious society or a church . . . ." 61 However, its approach suggests a possible legal standard of accepting a group as religious when the practices in which the members of the group engage are similar or equivalent to those of recognized religions. It

56 The Supreme Court used this part of the California court's definition (without acknowledgment) in United. States v. Seeger, 380 U.S. 163, 165-66 (1965).

57249 F.2d. 127 (D.C. Cir. 1957).

58 D.C. CODE ANN. $\$ 47-801$ (a) (m) (1966):

59249 F.2d at 128.

60 Id. at 129.

o1 Id. 
may be noted that the activities which the court mentions have been regarded here as the definition of a religious institution if they are expressions of beliefs that some individuals regard as religious. But "equivalence of practice" fails as a standard; on the face of it, at least, a tribal dance or the handling of snakes have as much claim to religion as the reading from the Bible or the taking of bread and wine. Such a standard would tend to prejudice recognition of novel or strange institutions of religion. What must be decisive in a test is whether the practices confirm, promote or express a belief which is religious to some people.

The most important recent judicial statement defining religion appears in the 1965 decision of United States $v$. Seeger. ${ }^{62}$ The opinion concerned three conscientious objectors, each of whom believed in something other than the traditional Supreme Being as the basis of their alleged religion. The issue was whether such beliefs were religious within the conscientious objector provision of the Universal Military Training and Service Act of 1948:

Religious training and belief in this connection means an individual's belief in a relation to a Supreme Being involving duties superior to those arising from any human relation, but does not include essentially political, sociological, or philosophical views or a merely personal moral code. ${ }^{63}$

Alternatively, the question was whether this definition constitutes an impermissible classification under the due process clause of the fifth amendment, because it fails to embrace all faiths which can validly claim to be called religious.

One of the cases before the court came from the Court of Appeals for the Ninth Circuit, ${ }^{64}$ which had held that the statutory language followed the distinction that court had made in Berman ${ }^{65}$ and, thus, that the defendant's belief could not be regarded as religious for legal purposes.

The second case came from the second circuit, which in United States v. Jakobson, ${ }^{66}$ took an entirely different view of the matter. It noted that in Torcaso $v$. Watkins ${ }^{67}$ the Supreme Court held that the first amendment forbade "aid [to] those religions based on a

62380 U.S. 163 (1965).

6350 U.S.C. App. § 456(j) (1958).

64 Peter v. United States, 324 F.2d 173 (9th Cir. 1963).

65 Berman v. United States, 156 F.2d 377 (9th Cir.), cert. denied, 329 U.S. 795 (1946). See text accompanying notes 6-8. The court observed that the Senate Armed Services Committee Report cited Berman in commenting on the insertion of the new language. See note 75 infra.

66325 F.2d 409 (2d Cir. 1963).

67367 U.S. 488 (1961). 
belief in an existence of God as against those religions founded on different beliefs;" ${ }^{68}$ since this conscientious objector provision aids religion, the exemption in order "to avoid 'grave and doubtful constitutional questions . . . " must be construed "as broadly as the words permit." ${ }^{69}$ Thus construed, the court held that the statute does not require an "anthropomorphic deity" 70 or a "God up there." 71 Without supplying its own definition of religion, it said the term surely must encompass views like Paul Tillich's-views which were similar to the defendant's. The court did not deal with the problem of what happens if a belief is so unorthodox or so newly founded as to be unlike those of any known theologian, a difficulty which arises whenever a standard involves comparison of the content of one belief to another.

The third case before the Supreme Court in Seeger also came from the second circuit, and also resulted in the recognition of a non-theistic belief as religious. But the second circuit's conclusion in Seeger ${ }^{72}$ was based on its holding that the "Supreme Being" requirement in the statute was an impermissible classification which violated the due process clause of the fifth amendment:

. . . legislative power to deny a particular privilege altogether does not imply an equivalent power to grant such a privilege on unconstitutional conditions. ... [A] requirement of belief in a Supreme Being, no matter how broadly defined, cannot embrace all those faiths which can validly claim to be called "religious." 73

The Court did not propose an alternative to the congressional standard for distinguishing between religion and non-religion.

Thus the Supreme Court decision in United States v. Seeger was written on a record of three very different, if incomplete, treatments of the same statutory language. Its own holding followed the broad lines of the Jakobson opinion, stating that belief in something other than the traditional Supreme Being can qualify as a religion in terms of the Congressional definition. The Supreme Being clause, the Court held, was "no more than a clarification of the 1940 provision involving

$68 I d$. at 495.

69 United States v. Jakobson, 325 F.2d 409, 415 (2d Cir. 1963).

$70 \mathrm{Id}$.

71 Id.

72 United States v. Seeger, 326 F.2d 846 (2d Cir. 1964).

73 Id. at $851,852$. 
only certain 'technical amendments,' to use the words of Senator Gurney," 74 who was "Chairman of the Senate Armed Services Committee and sponsor of the Senate bill containing the present version of $\S 6(j)$." 75 Thus, under this Act, as before, "it was necessary only to have a conviction based upon religious training and belief." 78 The language was inserted simply to "clari[fy] the meaning of religious training and belief so as to embrace all religions and to exclude essentially political, sociological, or philosophical views." 77 In explaining the standard, the Court said:

. . . the test of belief "in a relation to a Supreme Being" is whether a given belief that is sincere and meaningful occupies a place in the life of its possessor parallel to that filled by the orthodox belief in God of one who clearly qualifies for the exemption. Where such beliefs have parallel positions in the lives of their respective holders we cannot say that one is "in a relation to a Supreme Being" and the other is not. ${ }^{78}$

The Court's approach thus surmounts the difficulties in the lower court opinions. In contrast to the ninth circuit's approach, its formulation takes account of all religious beliefs, including those not involving traditional concepts of God. Furthermore, in accepting the Congressional standard as a valid way of defining religion, the Court interprets the definition so as to avoid a comparison of the content of one belief with that of another. It is the psychological significance of the belief to the believer which is crucial, rather than the substantive content of the belief. The key question is: what place does the belief occupy in the life of its possessor?

But it may be argued that this question, and the Court's standard generally, is too vague. Under it, for example, if a person believes in something with great zeal, his belief may be said to be religious on the ground that orthodox religious beliefs have been held with great zeal. However, the Court guards against this erroneous interpretation of its standard by stating:

74380 U.S. at 179.

75 Id. The Senate Armed Services Committee Report had cited the Berman decision directly in commenting on the insertion of the new language. The Supreme Court was thus pressed to explain that citation. It said the same Report "specifically states that $\S 6(j)$ was intended to re-enact 'substantially the same provisions as were found' in the 1940 Act"; furthermore, there was no indication of any Congressional concern over any conflict between Kauten and Berman. Id. at 176, 178.

76 Id, at 176.

77 Id. at 165 .

78 Id. at $165-66$. 
Within [the phrase, "religious training and belief"] would come all sincere religious beliefs which are based upon a power or being, or upon a faith, to which all else is subordinate or upon which all else is ultimately dependent. ${ }^{79}$

In other words, belief must be in a final reality of some kind-a power or being or faith-to which all else is subordinate or upon which all else is ultimately dependent. A zealously held belief in something does not necessarily occupy a place parallel to the belief in God; rather, the key is the relationship between the power or being or faith, on the one hand, and the universe, on the other. This relationship will have an explanatory function for the believer; it will put things in perspective much in the same way as a belief in God does. It will serve to relate the individual believer to his fellow man and the universe. Moreover, there is a limit to religion: it is a belief which has an explanatory force to the believers and thereby involves a reality to which everything else is subordinate or ultimately dependent.

The Supreme Court's standard thus at least partially achieves the same objective as the standard proposed here: it broadens the definition of religion and at the same time keeps the term meaningful. That broadened legal definition is consistent with contemporary religious developments as they are understood by the believers themselves. ${ }^{80}$

At the same time, the Court avoids some of the pitfalls in previous attempts to formulate a non-theistic definition. As in the formulation proposed here, the Court did not attempt to compare the content of one belief to another. It did not compare the practices of one religious claimant to those of another. In these ways, the Court's standard helps to prevent discrimination against beliefs that seem incredible, or practices which seem strange viewed from the perspective of familiar religious practices.

On the other hand, it is true that in the Seeger case, the Supreme Court did not deal with institutional questions in its definition. It is also true that in this area much of the confusion in judicial opinions has existed in the past; courts have seemed to reject the religious status of a practice in deciding a free exercise claim. ${ }^{81}$ Not only does a theoretical view of religion demand a consistent treatment of these problems, but the allegation that an institution is religious invariably is an important issue in decisions under the establishment clause. A

79 Id. at 176.

80 See, e.g., note 47 supra and accompanying text.

81 State v. King Colony Ranch, 137 Mont. 145, 350 P.2d 841 (1960) ; People v. Ashley, 184 App. Div. 520, 172 N.Y.S. 282 (1918). But cf. Sheldon v. Fannin, 221 F. Supp. 766 (D. Ariz. 1963). 
non-theistic definition does not preclude a solution to these problems, ${ }^{82}$ but they were not before the Court in Seeger. ${ }^{83}$

In sum, while courts in recent years have moved toward a nontheistic definition of religion, none has had occasion, either in a single decision, or in a series of decisions, to supply a definition which is theoretically sound and which is at the same time comprehensive. Nevertheless, such a definition is important, since legal privileges and exemptions accrue to the status of religion. These benefits should not be applied in a discriminatory manner because the definition of religion is inadequate. It is simultaneously necessary that "religion" be limited in such a way that the classification does not become meaningless. The non-theistic definition proposed here, analyzing religion in both its operational and institutional aspects, should succeed in establishing a universal standard with sufficient limits to be legally meaningful.

82 In terms of the establishment clause, religion refers to the majority's concept of the term, while under the free exercise clause, it refers to the minority's concept. See Sheldon v. Fannin, 221 F. Supp. 766 (D. Ariz. 1963). This thought has been developed in terms of the definitional scheme proposed here in S. Boyan, The Expanding View of the Free Exercise of Religion Clause, Sept. 1966 (unpublished Ph.D. dissertation in University of Chicago Library).

83 In fact, even the meaning of "religion" under the free exercise clause was not before the Court; only the interpretation of particular statutory language was. It may be doubted, in light of the Court's view in Torcaso v. Watkins, 367 U.S. 488 (1961), that the standard under the more general language of the first amendment would be less liberal. It may also be noted that recently Congress has eliminated the "Supreme Being" clause in the Military Selective Service Act of 1967, 50 U.S.C.A. App. \$456(j) (Supp. 1967). According to the Report of the House Armed Services Committee, "the Director of Selective Service advised the Committee . . . that in his judgment this undue expansion [in United States $v$. Seeger] of the provision of the law relating to conscientious objection could very easily result in a substantial increase in the number of unjustified appeals for exemption from military service based upon this provision of the law." H.R. REP. No. 267, 90th Cong., 1st Sess. 31 (1967). It is difficult to say, however, how this change will secure the desired effect. The section now reads like the Selective Training and Service Act of 1940 provisions on the subject, see note 17 supra, under which a number of liberal interpretations were given. See note 28 supra and accompanying text. See also note 32 supra. Furthermore, the "Supreme Being" clause seemed to be a restriction on what beliefs a court could recognize as religious; but for the Committee report, removal of the provision would seem to broaden judicial discretion. 